\title{
WASTAFEL PORTABLE SEBAGAI UPAYA PENCEGAHAN COVID-19 DI DESA KLAYAN
}

\section{Portable Washbasin as an Effort to Prevent Covid-19 in Klayan Village}

\author{
Budi Tri Prasetyo ${ }^{1}$, Aan Kunaedi ${ }^{2}$, Ani Suryani ${ }^{1}$, Supriyatno $^{1}$ \\ ${ }^{1}$ Universitas Muhammadiyah Cirebon \\ ${ }^{2}$ Sekolah Tinggi Farmasi Muhammadiyah Cirebon \\ ankunaedi@gmail.com
}

\begin{abstract}
ABSTRAK
Pada akhir tahun 2019 muncul kasus serupa dengan pneumonia yang tidak diketahui di Wuhan, China. Saat ini, wabah Coronavirus Disease (Covid-19) menjadi isu kesehatan yang paling menghebohkan seluruh dunia, termasuk Indonesia. Penanggulangan ekstrem seperti isolasi suatu daerah (lockdown) bahkan suatu negara pun dilakukan sebagai upaya untuk meminimalisir penyebaran penyakit tersebut. Coronavirus merupakan virus subfamili Orthocronavirinae dalam keluarga Coronaviridae dan ordo Nidovirales. Virus ini dapat menyebabkan penyakit pada burung dan mamalia, termasuk manusia. Gejala Covid-19 antara lain demam, batuk kering, dan sesak napas. Beberapa pasien mengalami gejala mirip pilek dan mengalami nyeri pada tenggorokan dan diare. Beberapa orang yang terinfeksi tidak menunjukkan gejala dan merasa sehat. Mencuci tangan dengan sabun salah satu upaya mencegah penularan virus Covid-19. Kandungan sabun terbukti secara klinis mampu membunuh bakteri, virus, dan kuman penyakit. Mencuci tangan dengan sabun adalah langkah dasar yang paling mudah dan aman untuk melindungi diri dari virus dan merupakan anjuran dari WHO. Metode yang digunakan dalam pengabdian kepada masyarakat ini yaitu sosialisasi cuci tangan dan pendampingan pembuatan wastafel portable. Dimulai dengan kegiatan survey lokasi pengabdian, pembuatan desain wastafel, pembuatan wastafel, penyerahan wastafel ke perwakilan Desa Klayan, pelatihan penggunaan wastafel portable dan penyuluhan cara cuci tangan yang baik, serta pelatihan perawatan wastafel.
\end{abstract}

Kata kunci: Coronavirus-19, Cuci Tangan, Wastafel Portable

\section{ABSTRACT}

At the end of 2019, a similar case of unknown pneumonia emerged in Wuhan, China. Currently, the Coronavirus Disease (Covid-19) outbreak is the most horrendous health issue in the world, including Indonesia. Extreme countermeasures such as isolation of an area (lockdown) and even a country are carried out in an effort to minimize the spread of the disease. Coronavirus is a subfamily Orthocronavirinae virus in the Coronaviridae family and the order Nidovirales. This virus can cause disease in birds and mammals, including humans. Symptoms of Covid-19 include fever, dry cough, and shortness of breath. Some patients experience cold-like symptoms and experience sore throat and diarrhea. Some people who are infected have no symptoms and feel well. Washing hands with soap is an effort to prevent transmission of the Covid-19 virus. The content of soap is clinically proven to be able to kill bacteria, viruses, and germs. Washing your hands with soap is the easiest and safest basic step to protect 
yourself from viruses and is a recommendation from WHO. The method used in this community service is the socialization of handwashing and assistance in making portable handwashing. Starting with the activity of surveying the service location, making sink designs, making sinks, handing over the sinks to representatives of Klayan Village, training in using portable sinks and counseling on good hand washing methods, as well as sink maintenance training.

Keywords : Coronavirus-19, Handwash, Portable Sink

\section{PENDAHULUAN}

Pada 31 Desember 2019 muncul kasus serupa dengan pneumonia yang tidak diketahui di Wuhan, China. Kasus tersebut diakibatkan oleh virus corona atau yang dikenal dengan COVID19 (Corona Virus Desese-2019) (Herliandry, dkk, 2020). Pada tanggal 11 Maret 2020, WHO (World Health Organization) menyatakan wabah penyakit akibat virus corona Covid-19 sebagai pandemi global. Dinyatakan status ini diakibatkan kasus positif di luar China yang meningkat tiga belas kali lipat 114 negara dengan total kematian pada saat itu mencapai 4,291 orang (Valerisha dan Marshell, 2020).

Saat ini, wabah Coronavirus Disease (Covid-19) menjadi isu kesehatan yang paling menghebohkan seluruh dunia, termasuk Indonesia. Penanggulangan ekstrem seperti lockdown suatu daerah bahkan suatu negara pun dilakukan sebagai upaya untuk meminimalisir penyebaran penyakit tersebut.Belakangan ternyata ditemukan bahwa diameter virus corona diperkirakan mencapai 125 nanometer atau 0,125 mikrometer. Satu mikrometer sama dengan 1000 nanometer. Kecil sekali dan tak mungkin pandangan telanjang manusia mampu melihatnya. Sekalipun sangat kecil dan manusia yang tak mau berpikir meremehkannya, virus ini mampu bertahan lebih dari 10 menit di permukaan, termasuk tangan. Bahkan WHO menyebut virus corona baru (Covid-19) dapat bertahan selama beberapa jam, bahkan beberapa hari dan dapat bertahan hidup di suhu 26-27 derajat celcius (Zahrotunnimah, 2020).

Coronavirus adalah sekumpulan virus dari subfamili Orthocronavirinae dalam keluarga Coronaviridae dan ordo Nidovirales. Kelompok virus ini yang dapat menyebabkan penyakit pada burung dan mamalia, termasuk manusia. Pada manusia, coronavirus menyebabkan infeksi saluran pernapasan yang umumnya ringan, seperti pilek, meskipun beberapa bentuk penyakit seperti; SARS, MERS, dan COVID-19 sifatnya lebih mematikan (Yunus dan Annissa 2020).Gejala Covid-19 antara lain demam, batuk kering, dan sesak napas. Beberapa pasien mengalami gejala mirip pilek dan mengalami nyeri pada tenggorokan dan diare. Beberapa orang yang terinfeksi tidak menunjukkan gejala dan merasa sehat. Sebagian dapat pulih dengan sendirinya, sedangkan sebagian lainnya mengalami perburukan kondisi sehingga mengalami kesulitan bernapas dan perlu dirawat di rumah sakit (Sari, 2020).

Virus Covid-19 telah mewabah di Indonesia sejak awal maret. Hingga 12 Mei 2020 terdapat 17.514 kasus positif terkonfirmasi tersebar di 34 provinsi dan 415 kabupaten/kota (Herliandry, dkk, 2020). Berdasarkan data dari Pusat layanan data dan informasi Covid-19 
Kabupaten Cirebon tercatat sampai tanggal 8 Septemper 2020 terdapat 365 orang telah terkonfirmasi yaitu 118 orang dengan gejala, 247 orang tanpa gejala, 18 orang mening gal, 130 orang selesai isolasi, dan 217 orang dirawat (PUSICOVCIREBON).

Dengan makin bertambahnya kasus yang terkonfirmasi virus corona, pemerintah menghimbau kepada masyarakat untuk mematuhi protokol kesehatan yang salah satunya yaitu mencuci tangan menggunakan sabun dan air yang mengalir. Tangan adalah salah satu anggota tubuh yang harus dijaga kebersihannya, karena tangan sering terkontaminasi kotoran maupun mikroba sehingga dengan melalui perantara tangan mikroba akan masuk kedalam tubuh (Nakoe, 2020). Mencuci tangan pakai sabun adalah salah satu upaya pencegahan melalui tindakan sanitasi dengan membersihkan tangan dan jari jemari menggunakan air dan sabun. Tangan manusia seringkali menjadi agen yang membawa kuman dan menyebabkan patogen berpindah dari satu orang atau dari alam ke orang lain melalui kontak langsung atau tidak langsung (Mustikawati, 2017).

Mencuci tangan dengan sabun mencegah penularan virus Covid-19. Kandungan sabun terbukti secara klinis mampu membunuh bakteri, virus, dan kuman penyakit. Mencuci tangan dengan sabun adalah langkah dasar yang paling mudah dan aman untuk melindungi diri dari virus dan merupakan anjuran dari WHO. Virus Covid-19 bisa berada di mana saja, menempel di benda-benda yang ada di sekitar kita. Membiasakan diri mencuci tangan dengan sabun dan air mengalir ini penting dilakukan. Ini yang akan jadi kunci untuk membunuh, merusak, dan mematikan virus yang mencemari tangan kita (Sinaga, dkk, 2020).

Perilaku mencuci tangan ini akan sangat efektif untuk memutus rantai penyebaran virus tersebut. Hal ini disebabkan virus Covid-19 selain menular melalui batuk dan bersin, juga menular melalui perantara benda di sekeliling kita yang baru saja dipegang oleh pasien yang terkena penyakit Covid-19. Jika kita memegang benda yang baru saja dipegang oleh pasien Covid-19 dan memegang mulut atau hidung, kita akan ikut tertular. Kondisi ini dapat diputus dengan cara, jangan mudah memegang benda di sekitar menggunakan tangan dan minimalisir memegang mulut dan hidung. Apabila terpaksa harus memegang benda di sekitar kita dan harus memegang mulut atau hidung, kita wajib melakukan cuci tangan dengan sabun agar virus Covid-19 mati (Saputra, dkk, 2020).

Keberadaan budaya perilaku bersih melalui cuci tangan ini dapat dilakukan semua pihak dimulai dari individu, keluarga, masyarakat, akademisi, dunia usaha, organisasi kemasyarakatan, dan organisasi profesi. Para pemangku pihak ini bersinergi dengan Pemerintah Pusat dan Daerah untuk berperilaku sehat (Ibrahim, dkk, 2020). Untuk mendukung budaya perilaku bersih melalui cuci tangan sebagai salah satu upaya pencegahan penyebaran Covid-19 di beberapa tempat umum perlu disediakannya fasilitas yang memadai yang salah satunya adalah fasilitas tempat cuci tangan atau wastafel dengan sabun. Namun, permasalahannya tidak 
semua tempat umum dapat dengan mudah dipasang wastafel sehingga diperlukan wastafel portabel yang mampu dipindah-pindahkan sesuai dengan kebutuhan.

Berdasarkan hasil survey tempat yang telah kami lakukan sebelumnya ditemukan bahwa di Desa Klayan belum terdapat fasilitas umum yang dapat digunakan oleh masyarakat untuk mencuci tangan menggunakan sabun terutama jika sedang diadakan suatu acara, sulit untuk menemukkan fasilitas umum yang dapat digunakan untuk mencuci tangan. Oleh karena itu kami mencoba membuat fasilitasi umum berupa wastafel yang bisa dipindahkan dari satu tempat ke tempat lain menyesuaikan kebutuhan. Selain itu, wastafel juga harus bisa dimasukkan atau disimpan saat sudah tidak ada aktivitas atau pada waktu jam kerja kantor desa sudah selesai. Jika tidak disimpan, wastafel bisa digunakan anak-anak untuk bermain dan bisa rusak. Dengan adanya wastafel portable ini, jika masyarakat atau desa mengadakan suatu acara terutama di ruangan terbuka, fasilitas umumuntuk cuci tangan akan tetap tersedia karena mudahnya wastafel untuk dipindahkan, wastafel juga mudah untuk disimpan jika sudah tidak terpakai sehingga wastafel lebih terawat dan tidak mudah rusak.

Berdasarkan uraian tersebut, tujuan dari pelaksanaan Pengabdian Kepada Masyarakat di Desa Klayan, Kecamatan Gunung Jati, Kabupaten Cirebon yaitu membuat wastafel portable dan diberikan untuk dimanfaatkan oleh masyarakat dan perangkat Desa Klayan dalam upaya pencegahan penyebaran Covid-19.

\section{BAHAN DAN METODE}

Metode yang digunakan dalam pengabdian kepada masyarakat ini yaitu dimulai dengan kegiatan survey lokasi pengabdian, pembuatan desain wastafel, pembuatan wastafel, penyerahan wastafel ke perwakilan Desa Klayan, pelatihan penggunaan wastafel portable dan penyuluhan cara cuci tangan yang baik, serta pelatihan perawatan wastafel. a) Tahapan pertama diawali dengan pendataan permasalahan lokasi pengabdian Desa Klayan. b) Tahapan Kedua, setelah diskusi solusi permasalahan diantaranya tersedianya tempat cuci tangan umum guna meminimalisir penyebaran virus. Pembuatan desain wastafel portable untuk merencanakan wastafel portable yang dibutuhkan masyarakat Desa Klayan sesuai dengan hasil observasi kemitraan Desa Klayan. c) Penyerahan wastafel portable dilakukan setelah selesai dibuat kepada pihak kemitraan. d) Pelatihan penggunaan wastafel portable dan penyuluhan cara cuci tangan yang baik dilakukan pada saat serah terima wastafel portable sebagai upaya pengenalan wastafel portabel dan tata cara penggunaan wastafel portable kepada kemitraan Desa Klayan. Dilanjutkan sosialisasi kepada masyarakat sekitar Desa Klayan. e) Pelatihan perawatan wastafel portable ini perlu dilakukan oleh pengelola, agar wastafel portable tetap bisa digunakan dengan baik. 
Pelaksanaan pengabdian ini dilakukan di Kantor Desa Klayan, Kecamatan Gunung Jati, Kabupaten Cirebon. Waktu pelaksanaan Kegiatan ini dilakukan pada 27-28 Agustus 2020 dan 4 September 2020.

\section{HASIL}

Kegiatan pengabdian ini sesuai harapan, seperti ditunjukkan pada gambar 1. Tersedia wastafel portable yang ditempatkan di area umum, dapat digunakan semua masyarakat desa. Sehingga tujuan budidaya rajin mencuci tangan guna meminimalisir penyebaran Covid-19 diharapkan dapat tercapai. Penekanan angka penyebaran covid-19, khususnya didaerah Desa Klayan dapat lebih diminimalisir. Selain bertujuan menekan angka penyebaran covid-19, diharapkan dengan kegiatan ini dapat menginspirasi kreatifitas sumber pendapatan dan perekonomian warga sekitar dengan memproduksi wastafel portabel tersebut.

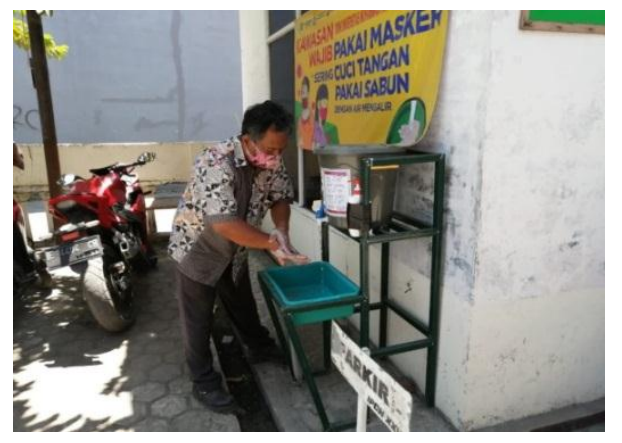

\section{Gambar 1. Masyarakat menggunakan fasilitas wastafel portable}

\section{PEMBAHASAN}

Covid-19 yang merupakan keluarga besar Coronavirus yang dapat menyerang hewan dan manusia. Ketika menyerang manusia, Coronavirus biasanya menyebabkan penyakit infeksi saluran pernafasan, seperti flu, MERS (Middle East Respiratory Syndrome), dan SARS (Severe Acute Respiratory Syndrome). COVID-19 sendiri merupakan coronavirus jenis baru yang ditemukan di Wuhan, Hubei, China pada tahun 2019 (Setiawan, 2020).

Berdasarkan data dari Pusat layanan data dan informasi Covid-19 Kabupaten Cirebon tercatat sampai tanggal 8 Septemper 2020 terdapat 365 orang telah terkonfirmasi yaitu 118 orang dengan gejala, 247 orang tanpa gejala, 18 orang meninggal, 130 orang selesai isolasi, dan 217 orang dirawat (PUSICOVCIREBON). Berdasarkan informasi tersebut diperlukan upaya pencegahan penyebaran covid-19 sehingga menekan peningkatan penyebaran pasien terpapar covid-19, salah satu upaya pencegahannya dengan meningkatkan budaya cuci tangan menggunakan sabun dan air yang mengalir.

Kantor Desa Klayan seperti pada gambar 2, Kecamatan Gunung Jati merupakan salah satu area yang terdampak Covid-19. Sehingga diperlukan kewaspadaan tinggi kepada 
masyarakat agar menekan lonjakan pasien Covid-19 di Kabupaten Cirebon, khususunya Kecamatan Gunung Jati dan Desa Klayan dengan cara meningkatkan kesadaran budaya sehat dan cuci tangan setiap waktu. Pelaksanaan survey tanggal 28 Juli 2020 yang ditunjukkan pada gambar 3, diketahui beberapa langkah yang sudah dilakukan oleh Kantor Desa Klayan untuk mengantisipasi penyebaran Covid-19, yaitu dengan melakukan penyuluhan Covid-19 berupa spanduk dan poster, penyemprotan desinfektan secara berkala serta penggunaan wajib masker di area Desa Klayan.

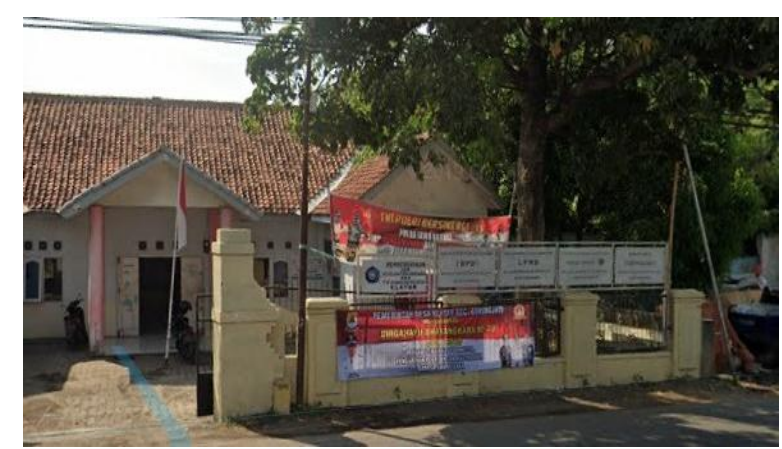

Gambar 2. Kantor Desa Klayan

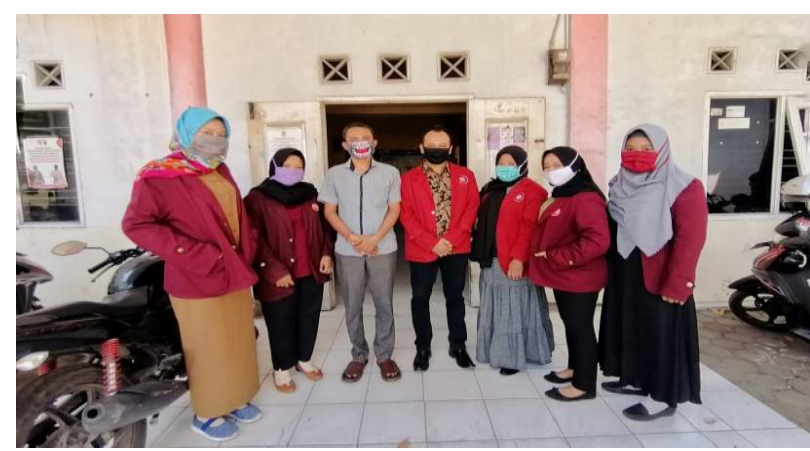

Gambar 3. Survey ke Kantor Desa Klayan

Berdasarkan survey di Desa Klayan, sedikit tersedia fasilitas cuci tangan umum yang fleksibel dan mudah dipindahkan. Mengatasi permasalahan itu diperlukan adanya solusi yaitu membuat fasilitas cuci tangan atau wastafel portabel untuk ditempatkan ke tempat yang strategis dan dapat dipindahkan sesuai dengan kebutuhan. Tujuan dari pengabdian ini menyediakan wastafel portabel di Kantor Desa Klayan sebagai upaya untuk memutus mata rantai penyebaran Covid-19. Setelah pelaksanaan survey, kami melakukan pembuatan desain wastafel portable yang sesuai dengan kebutuhan dari Kantor Desa Klayan. Hasil desain yang sudah dibuat selanjutnya dilakukan pembuatan wastafel portable yang terlihat pada gambar 4 dan hasil produk ditunjukkan pada gambar 5. 


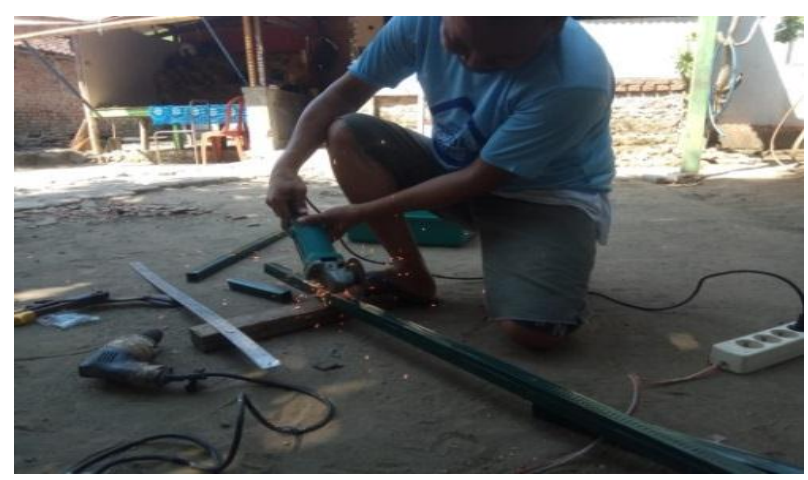

Gambar 4. Pembuatan wastafel portable

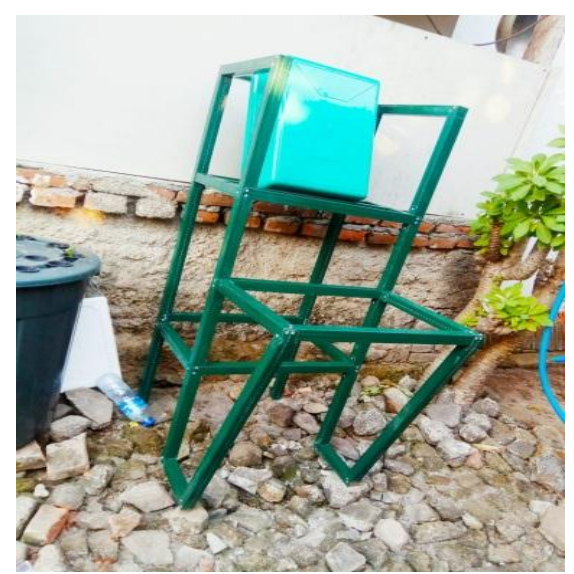

\section{Gambar 5. Kerangka wastafel portable}

Wastafel portable yang sudah dibuat diserahkan secara simbolis kepada perwakilan Desa Klayan pada tanggal 4 September 2020. Dokumentasi penyerahan secara simbolis wastafel portable kepada Desa Klayan pada gambar 6.

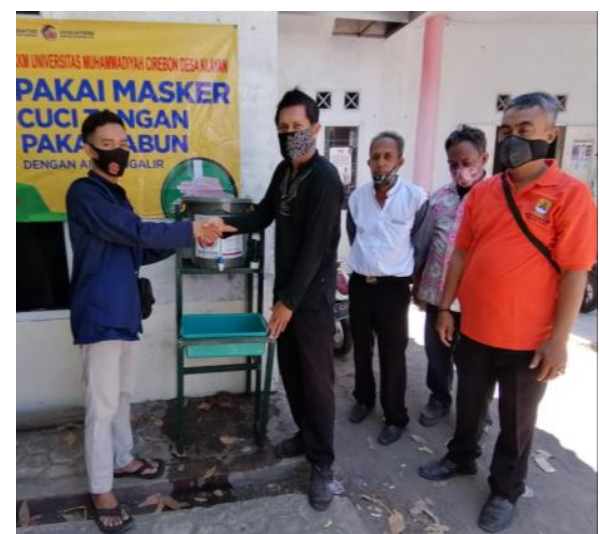

\section{Gambar 6. Penyerahan wastafel portable kepada perwakilan Desa Klayan}

Selain kegiatan penyerahan wastafel portable dilakukan juga pelatihan perawatan wastafel portable serta penyuluhan cara cuci tangan yang baik. Dengan adanya wastafel portable 
ini masyarakat menjadi lebih memperhatikan kebersihan dengan cara mencuci tangan menggunakan sabun dan air mengalir terutama setelah selesai berkegiatan. Selain itu, melalui program ini diharapkan masyarakat dapat membuka suatu usaha mandiri berupa jasa pembuatan wastafel portable yang pada akhirnya dapat meningkatkan perekonomian masyarakat sekitar Desa Klayan. Adanya program ini disambut baik oleh perangkat desa serta masyarakat sekitar, mereka rutin merawat dan membersihkan wastafel portable agar wastafel portable tetap layak digunakan. Bentuk tindak lanjut dari program ini diharapkan adanya kerjasama antara perangkat desa dan masyarakat dalam rangka menumbuhkan semangat hidup bersih dan sehat. Hidup bersih dan sehat juga merupakan semua perilaku kesehatan yang dilakukan atas kesadaran seseorang sehingga dapat menangani dirinya sendiri dalam hal kesehatan serta dapat berperan aktif dalam kegiatan-kegiatan kesehatan baik bagi inidividu masing-masing maupun orang lain, salah satu upaya hidup bersih dan sehat dapat dilakukan dengan rajin mencuci tangan setelah berkegiatan (Tentama, 2017). Mengingat betapa pentingnya pola hidup bersih dan sehat terutama dalam situasi pandemik Covid-19 ini. Adapun kendala yang kami temukan selama proses pelaksanaan program ini adalah di Rancangan Anggaran Biaya untuk pembuatan wastafel, kami berusaha mencari bahan baku yang kokoh namun berharga terjangkau agar masyarakat yang ingin membuka usaha jasa pembuatan wastafel portable ini nantinya tidak terbebani oleh modal usaha.

Penerapan wastafel portable ini diharapkan mampu dimanfaatkan oleh kantor Desa Klayan secara maksimal dan dapat memutus rantai penyebaran Covid-19 di kawasan Desa Klayan Kecamatan Gunung Jati.

\section{KESIMPULAN DAN SARAN}

Penerapan wastafel portable di kantor Desa Klayan sudah sesuai dengan fasilitas yang dibutuhkan oleh pihak desa dan masyarakat. Wastafel portable ini kedepannya akan dimanfaatkan secara maksimal oleh pihak Desa Klayan sebagai salah satu upaya memutuskan rantai penyebaran Covid-19 dengan cara mencuci tangan menggunakan sabun dan air mengalir di kawasan Desa Klayan Kecamatan Gunung Jati. Diharapkan juga baik dari pihak desa maupun masyarakat sekitar dapat merawat wastafel portable agar tetap layak digunakan. Selain itu, melalui program ini diharapkan masyarakat dapat membuka suatu usaha mandiri berupa jasa pembuatan wastafel portable yang pada akhirnya dapat meningkatkan perekonomian masyarakat sekitar Desa Klayan.

\section{UCAPAN TERIMA KASIH}

Ucapan terima kasih kepada Allah SWT yang telah memberikan kelancaran pada setiap kegiatan yang kami laksanakan. Bapak Iman Sahudi selaku Kuwu Desa Klayan beserta 
jajarannya. Masyarakat Desa Klayan yang telah memberikan kontribusi dan partisipasi kepada kami dalam setiap kegiatan sehingga dapat terlaksana dengan lancar. Dewan Pembimbing Lapangan (DPL) Apt., H. Bapak Aan Kunaedi, M.Sc beserta jajaran LPPM Universitas Muhammadiyah Cirebon yang telah membimbing dan memberikan masukan atas terlaksananya kegiatan ini. Seluruh kelompok KKM Kecamatan Gunung Jati yang telah bekerjasama sehingga semua kegiatan dapat terlaksana dengan lancar. Semoga kegiatan ini dapat bermanfaat dan membantu untuk memutuskan rantai penyebaran Virus Covid-19 di Desa Klayan.

\section{DAFTAR PUSTAKA}

Herliandry, dkk.(2020). Pembelajaran pada masa pandemic covid-19.Jurnal Teknologi Pendidikan, 22 (1), 65-70.

Ibrahim, dkk. (2020). Bencana virus corona melalui sosialisasi pada anak usia dini pada Desa Rempe Kecamatan Seteluk Sumbawa Barat. Selaparang: Jurnal Pengabdian Masyarakat Berkemajuan, 13 (2), 191-195.

Mustikawati, Intan Silviana. (2017). Perilaku cuci tangan pakai sabun: studi kualitatif pada ibu-ibu di kampong nelayan muara angke Jakarta Utara. ARKESMAS, 2 (1), 115-125.

Nakoe, dkk. (2020). Perbedaan efektivitas hand-sanitizer dengan cuci tangan menggunakan sabun sebagai bentuk pencegahan covid-19. Jambura Journal of Health Sciences and Research, 2 (2), 65-70.

Saputra, dkk. (2020). Penerapan wastafelportable sebagai upaya pencegahan covid-19 di kantor Kelurahan Gedongan Kecamatan Colomadu. Jurnal Pengabdian Kepada Masyarakat MEDITEG, 5 (1), 44-49.

Sari, Melani Kartika.(2020). Sosialisasi tentang pencegahan covid-19 di kalangan siswa sekolah dasar di SD Minggiran 2 Kecamatan Papar Kabupaten Kediri.Jurnal Karya Abdi, 4 (1), 80-83.

Setiawan, Adib Rifqi. (2020). Lembar kegiatan literasi saintifik untuk pembelajaran jarak jauh topik penyakit coronavirus 2019 (covid-19).Edukatif: Jurnal Ilmu Pendidikan, 2 (1), 28-37.

Tentama, Fatwa. (2017). Penerapan perilaku hidup bersih dan sehat (PHBS) demi kesejahteraan masyarakat Kecamatan Tuntang Kabupaten Semarang Jawa Tengah. Jurnal Pemberdayaan, 1 (1), 13-18.

Valerisha, Anggia dan Marshell Adi Putra. (2020). Pandemi global covid-19 dan problenatika Negara-bangsa: transparansi data sebagai vaksin socio-digital. Jurnal Ilmiah Hubungan Internasional. Tersedia: http://journal.unpar.ac.id/index.php/JurnalIlmiahHubunganInternasiona/article/vi ew/3871/2913

Yunus, Nur Rohim dan Annissa R. (2020).Kebijakan pemberlakuan lockdown sebagai antisipasi penyebaran corona virus covid-19.Salam: Jurnal Sosial dan Budaya Syar'i, 7 (3), 227-238.

Zahrotunnimah.(2020). Langkah taktis pemerintah daerah dalam pencegahan penyebaran virus corona covid-19 di Indonesia.Salam: Jurnal Sosial da Budaya Syar'i, 7 (3), 247-260.

Pusat Layanan Data dan Informasi Covid-19: Covid Center Kabupaten Cirebon. Tersedia: http://covid19.cirebonkab.go.id/ 
